\title{
Effects of milk-derived bioactives: an overview
}

\author{
Nagendra P. Shah* \\ School of Life Science and Technology, Victoria University of Technology, PO Box 14428, Melbourne City Mail Centre, \\ Victoria 8001, Australia
}

\begin{abstract}
Milk contains various components with physiological functionality. Peptides derived from caseins and whey proteins including opioid peptides, antihypertensive peptides, casein phosphopeptides, $\alpha$ - and $\beta$-lactorphins and albutensin have been shown to possess various bioactive properties. This review considers an overview of the bioactive components in milk proteins and whey and their physiological function.
\end{abstract}

Casein-based bioactive peptides: Casein phosphopeptides: Whey-based bioactive peptides: Opioid: Angiotensin I converting enzyme: $\alpha$-Lactorphin: $\beta$-Lactorphin

\section{Introduction}

The benefit of milk in preventing infection has been recognised for thousands of years. Much of this activity has been attributed to antibodies, but the role of other minor proteins such as lactoferrin and lactoperoxidase and of complex sugars in milk as bioactive agents is only now being recognised. Milk is a complete food for newborn mammals. It is the sole food during the early stages of rapid development. Milk contains approximately $5 \%$ lactose, $3.2 \%$ protein, $4 \%$ lipid and $0.7 \%$ mineral salts. The nutritional value of milk and milk products is due to these constituents.

Milk contains various components with physiological functionality. Milk contains high levels of immunoglobulins and other physiologically active compounds for warding off infection in the newborn. Similarly, colostrum is important for newly born mammals as it provides necessary immunity against infections. This review provides an overview of the bioactive components in milk and colostrum, their physiological functions and established and potential health implications and benefits.

\section{Physiological role of casein-based bioactive substances}

Casein is the main protein component of milk constituting about $80 \%$ of the total milk protein fraction. The concentration of casein, whey proteins and minor whey proteins in milk is shown in Table 1. Although, neither casein nor individual casein fractions have any established physiological role, peptides derived from casein have been shown to possess various bioactive properties. These bioactive peptides are hidden in an active state inside the polypeptide chain of caseins. Bovine casein consists of four components: $\alpha_{\mathrm{s} 1^{-}}, \alpha_{\mathrm{s} 2^{-}}, \beta-$ and $\kappa$-caseins (Walstra \& Jenness, 1984; Maubois \& Leonil, 1989). On the other hand, human casein consists of primarily $\beta$ - and $\kappa$-caseins. Bioactive peptides are produced by in vitro and in vivo enzymatic proteolysis of bovine or human casein and whey proteins as reviewed by several workers (Maubois \& Leonil, 1989; Yamauchi, 1992; Schlimme \& Meisel, 1993; Tirelli et al. 1997; Jelen \& Lutz, 1998).

A brief outline of bioactive peptides, their precursors and possible bioactive roles is shown in Table 2. Opioid peptides are those having pharmacological similarities to opium (morphine) and are derived from casein called casomorphins. The major opioid peptides as shown in Tables 2 and 3 derived from bovine milk are fragments of $\beta$-casein (Meisel \& Schlimme, 1990). The opioid peptides fragments of $\beta$-casein are called $\beta$-casomorphins due to their morphine-like behaviour. All $\kappa$-casein fragments known as casoxins, behave as opioid antagonists. Further opioid peptides are two $\alpha_{\mathrm{s} 1}$-casein exorphins $(\alpha$-casomorphins) which were found in pepsin hydrolysates of $\alpha$-casein (Fiat et al. 1993). A tetrapeptide amide, morphiceptin (Table 3 ) is the most active opioid agonist in the bovine $\beta$ casomorphin group. Two opioid antagonists, casoxin $\mathrm{C}$ and $\mathrm{D}$ also belong to this group (Loukas et al. 1983). All bioactive peptides derived from bovine $\alpha$-casein behave as opioid antagonists. Several immunomodulating peptides resulting from casein have been detected including immunopeptides from $\alpha_{\mathrm{s}}$-casein and $\beta$-casein. Casein phosphopeptides (CPPs) can be released in vitro and in vivo by gastrointestinal trypsin from $\alpha_{\mathrm{s} 1^{-}}, \alpha_{\mathrm{s} 2^{-}}$or $\beta$-caseins (Naito et al. 1972; Kitts \& Yuan, 1992; Tirelli et al. 1997).

Some peptides show antihypertensive activity (Maruyama \& Suzuki 1982; Maruyama et al. 1985). These peptides referred to casokinins (Table 4).

The angiotensin I converting enzyme (ACE) hydrolyses largely inactive angiotension I to the octapeptide angiotenson II, which increases blood pressure. This enzyme also hydrolyses bradykinin, which is a hypotensive. Thus ACE

* Corresponding author: Professor N. P. Shah, fax + 6139216 8284, email Nagendra.shah@vu.edu.au 
Table 1. Concentration and biological functions of major milk proteins

\begin{tabular}{|c|c|c|c|}
\hline \multirow[b]{2}{*}{ Protein } & \multicolumn{2}{|c|}{ Concentration $(g / l)$} & \multirow[b]{2}{*}{ Function } \\
\hline & Cow & Human & \\
\hline Total caseins & $26 \cdot 0$ & $2 \cdot 7$ & Ion carrier $\left(\mathrm{Ca}, \mathrm{PO}_{4}, \mathrm{Fe}, \mathrm{Zn}, \mathrm{Cu}\right)$ Precursors of bioactive peptides \\
\hline$\alpha$-Casein & $13 \cdot 0$ & & \\
\hline$\beta$-Casein & $9 \cdot 3$ & & \\
\hline к-Casein & $3 \cdot 3$ & & \\
\hline Total whey protein & $6 \cdot 3$ & $67 \cdot 3$ & \\
\hline$\beta$-Lactoglobulin & $3 \cdot 2$ & & Retinol carrier, binding fatty acids, possible antioxidant \\
\hline$\alpha$-Lactalbumin & $1 \cdot 2$ & 1.9 & Lactose- synthesis in mammary gland, Ca carrier, immunomodulation, anticarcinogenic \\
\hline Immunoglobulins (A, M, and $G)$ & 0.7 & 1.3 & Immune protection \\
\hline Serum albumin & 0.4 & 0.4 & \\
\hline Lactoferrin & $0 \cdot 1$ & 1.5 & Antimicrobial, antioxidative, immunomodulation, iron absorption, anticarcinogenic \\
\hline Lactoperoxidase & 0.03 & & Antimicrobial \\
\hline Lysozyme & 0.0004 & $0 \cdot 1$ & Antimicrobial, synergistic effect with immunoglobulins and lactoferrin \\
\hline Miscellaneous & $0 \cdot 8$ & $1 \cdot 1$ & \\
\hline Proteose-peptone & $1 \cdot 2$ & & Not characterised \\
\hline Glycomacropeptide & $1 \cdot 2$ & & Antiviral, bifidogenic \\
\hline
\end{tabular}

Adapted from Walstra \& Jenness (1984), Yamauchi (1992), Korhonen et al. (1998).

inhibitors are antihypertensive peptides. Other antihypersensitive peptides are located in the primary sequence of bovine $\beta$-lactoglobulin ( $\beta$-lactorphins) and human $\beta$ - and к-casein (Mullally et al. 1996).

The $\kappa$-casein fragment named casopiastrin obtained from tryptic hydrolysates, shows antithrombotic activity by inhibiting fibrinogen binding on platelets (Fiat et al. 1993).

Opioid peptides released from casein during digestion showed gastrointestinal motility (Daniel et al. 1990). Some of these peptides have been found to affect gastrointestinal transit time. Casomorphins have been found to prolong gastrointestinal transit time and to exert antidiarrhoeal action. The effect of $\beta$-casomorphins on the motility of rat intestinal tract was studied using the non-absorbable marker ${ }^{141} \mathrm{Ce}$.

The opioid peptides have shown morphin-like activity. When opioid peptides are injected into the bloodstream they induce an analgesic and sedative effect due to their action on the nervous system. $\alpha$-Lactorphin has been shown to exert a weak opioid activity to smooth muscles. $\beta$ Lactorphin has been shown to have a smooth musclecontracting effect (Antila et al. 1991). Teschemacher (1987) and Paroli (1988) also reported analgesic and sedative effects of opioid peptides when injected in the bloodstream.

Studies have suggested that opioid agonist and opioid antagonists are formed in the gut as a result of in vivo hydrolysis of milk casein. $\beta$-Casomorphins have been

Table 2. Bioactive peptides derived from bovine milk proteins

\begin{tabular}{lll}
\hline Bioactive peptide & \multicolumn{1}{c}{ Protein precursor } & \multicolumn{1}{c}{ Bioactivity } \\
\hline Casomorphins & $\alpha-, \beta$-Casein & Opioid agonists \\
Casokinins & $\alpha-, \beta$-Casein & Antihypertensive \\
Casoxins & $\kappa-$ Casein & Opioid antagonists \\
Casoplatelins & $\kappa$-Casein, transferrin & Antithrombotic \\
$\alpha$-Lactorphin & $\alpha$-Lactalbumin & Opioid agonist \\
$\beta$-Lactorphin & $\beta$-Lactoglobulin & Opioid agonist \\
Lactoferroxins & Lactoferrin & Opioid antagonists \\
Immunopeptides & $\alpha-, \beta$-Casein & Immunostimulants \\
Caseinophosphopeptides & $\alpha-, \beta$-Casein & Mineral carriers \\
\end{tabular}

Adapted from: Meisel \& Schlimme (1990); Schlimme \& Meisel (1993). detected in the plasma of pregnant or lactating women (Bicknell, 1985; Yen et al. 1985). Similarly, casomorphins have been detected in the duodenal chyme of minipigs and in the human small intestine (Svedberg et al. 1985) as a result of in vivo digestion.

In vitro activity of immunomodulating peptides resulting from tryptic and chymotryptic hydrolysates of $\alpha_{\mathrm{s} 1^{-}}$and $\beta$ casein has been reported to stimulate the macrophage activity against red blood cells (Parker et al. 1984). Caseinderived immunopeptides have been shown to stimulate the phagocytic activities of murine and human macrophages and to protect against Klebsiella pneumoniae infection in mice. The peptides may stimulate the proliferation and maturation of $\mathrm{T}$ cells and natural killer cells for the defence of the newborn against a large number of bacteria, particularly enteric bacteria. Injection of casein or $\alpha$ lactalbumin peptides has been found to have direct immunomodulating activity against Klebsiella pneumoniae in rats (Migliore-Samour et al. 1989). Lahov \& Regelson (1996) have reported antibacterial activity of isracidin, the 1-23 fragment of $\alpha_{\mathrm{s} 1}$-casein obtained from the action of chymosin, against Staphylococcus aureus and Candida

Table 3. Bioactive peptides derived from milk protein components: opioid peptides

\begin{tabular}{|c|c|c|c|}
\hline Peptides & & Origin & Structure \\
\hline \multicolumn{4}{|l|}{ Agonist } \\
\hline$\beta$-Casomorphin 5 & & $\beta-C N$ & Tyr-Pro-Phe-Pro-Gly \\
\hline$\beta$-Casomorphin 5 & $\mathrm{~h}$ & $\beta-C N$ & Tyr-Pro-Phe-Val-Glu \\
\hline Morphiceptin & & $\beta-C N$ & Tyr-Pro-Phe-Pro-NH \\
\hline$\alpha$-Casein exorphin & & $\alpha_{\mathrm{s} 1}-\mathrm{CN}$ & Arg-Gly-Phe-Gln-Asn-Ala \\
\hline \multicolumn{4}{|l|}{ Antagonist } \\
\hline Casoxin 4 & & $\kappa-C N$ & Tyr-Pro-Ser-Tyr $\left(\mathrm{O}-\mathrm{CH}_{3}\right)$ \\
\hline Casoxin A & & $\mathrm{K}-\mathrm{CN}$ & Tyr-Pro-Ser-Tyr-Gly-Leu-Asn-Tyr \\
\hline Casoxin B & $\mathrm{h}$ & $\kappa-C N$ & Tyr-Pro-Tyr-Tyr $\left(\mathrm{O}-\mathrm{CH}_{3}\right)$ \\
\hline Casoxin C & & $\kappa-C N$ & $\begin{array}{l}\text { Tyr-Ile-Pro-Ile-Gln-Tyr-Val-Leu- } \\
\text { Ser-Arg }\end{array}$ \\
\hline $\begin{array}{l}\text { Casoxin D } \\
\text { Lactoferroxin A }\end{array}$ & $\mathrm{h}$ & $\alpha_{s 1}-C N$ & Tyr-Val-Pro-Phe-Pro-Pro-Phe \\
\hline Lactoterroxın A & & & Iyr-Leu-Gly-Ser-Gily-Iyr $\left(-\mathrm{OCH}_{3}\right)$ \\
\hline
\end{tabular}

h, human.

Source: Yamauchi (1992). 
Table 4. Bioactive peptides derived from milk protein components: other groups

\begin{tabular}{|c|c|c|c|}
\hline Peptides & & Origin & Structure \\
\hline \multicolumn{4}{|l|}{ Peptides acting on smooth muscles } \\
\hline Albutensin A & & SA & Ala-Leu-Lys-Ala-Trp-Ser-Val-Ala-Arg \\
\hline$\beta$-Lactotensin & & $\beta-L G$ & His-Ile-Arg-Leu \\
\hline Casoxin C & & $\kappa-\mathrm{CN}$ & Tyr-Ile-Pro-Ile-GIn-Tyr-Val-Leu-Ser-Arg \\
\hline Casoxin D & $\mathrm{h}$ & $\alpha_{\mathrm{s} 1}-\mathrm{CN}$ & Tyr-Val-Pro-Phe-Pro-Pro-Phe \\
\hline \multirow[t]{6}{*}{ Angiotensin-converting enzyme inhibitor (ACEI) } & & $\alpha_{s 1}-C N$ & Phe-Phe-Val-Ala-Pro-Phe-Pro-Glu-Val-Phe-Gly-Lys \\
\hline & & $\alpha_{\mathrm{s} 1}-\mathrm{CN}$ & Thr-Thr-Met-Pro-Leu-Trp \\
\hline & & $\beta-\mathrm{CN}$ & Ala-Val-Pro-Try-Pro-Gln-Arg \\
\hline & $\mathrm{h}$ & $\beta-C N$ & Ser-Phe-GIn-Pro-GIn-Pro-Leu-Ile-Tyr-Pro \\
\hline & & $\beta-C N$ & Val-Val-Pro-Tyr-Pro-GIn-Arg \\
\hline & & $\beta-C N$ & Pro-Thr-His-Ile-Lys-Trp-Gly-Asp \\
\hline Casoxin A & & к-CN & Tyr-Pro-Ser-Tyr-Gly-Leu-Asn-Tyr \\
\hline $\begin{array}{l}\text { Casoxin C } \\
\text { Albutensin A }\end{array}$ & & $\begin{array}{l}\kappa-C N \\
\text { SA }\end{array}$ & Tyr-Ile-Pro-Ile-GIn-Tyr-Val-Leu-Ser-Arg \\
\hline \multirow[t]{2}{*}{ Phagocytosis-stimulating peptides $\mathrm{h}$} & & $\beta-\mathrm{CN}$ & Val-Glu-Pro-Ile-Pro-Try \\
\hline & & $\beta-C N$ & Leu-Leu-Tyr \\
\hline \multirow[t]{2}{*}{ Peptides inhibiting platelet function } & & $\kappa-C N$ & Pro-His-Leu-Ser-Phe \\
\hline & & $\begin{array}{l}\mathrm{k}-\mathrm{CN} \\
\mathrm{LF}\end{array}$ & $\begin{array}{l}\text { Met-Ala-Ile-Pro-Pro-Lys-Lys-Asn-Gln-Asp-Lys } \\
\text { Lys-Arg-Asp-Ser }\end{array}$ \\
\hline \multirow[t]{2}{*}{ DNA-synthesis stimulating peptide (BALB/c3T3 cell) } & & $\beta-C N$ & Ala-Val-Pro-Tyr-Pro-GIn-Arg (f 177-183) \\
\hline & $\mathrm{h}$ & $\beta-C N$ & $\beta-C N(f 1-18), \beta-C N$ (f $105-117)$ \\
\hline Glycomacropeptide & & $\kappa-C N$ & (f $106-169)$ \\
\hline Casein phosphopeptides & & $\alpha_{\mathrm{s} 1}-\mathrm{CN}$ & (f 43-79) (f 66-74) \\
\hline & & $\beta-C N$ & (f 1-25) \\
\hline
\end{tabular}

h, human.

Source: Yamauchi (1992).

albicans. The injection of isracidin into the udder of sheep and cow gave protection against mastitis.

In order to function physiologically in the human body, the active peptides must be absorbed from the intestine in an active form. However, there is no evidence that these peptides can be absorbed from the intestine in adults and the proposed properties remain to be proven. Di- and tripeptides can be easily absorbed in the intestine, however, it is not clear that larger bioactive peptides containing excess of three amino acids are absorbed from the intestine and reach the target organ. Yamamoto (1997) reported absorption of antihypertensive peptides, Val-Pro-Pro and Ile-Pro-Pro from sour milk.

The addition of CPPs to toothpaste formulas has been suggested to have anticariogenic effects and to prevent enamel demineralisation (Reynolds, 1994). CPPs are not unpalatable and can be used as an anticariogenic additive. Severe heat treatment of milk may cause dephosphorylation of phosphoseryl residues and may affect the bioavailability of CPP.

The casein phosphopeptides prevent the precipitation of calcium phosphate and increase the concentration of soluble calcium in vitro and also in the lumen of the small intestine of rat (Naito et al. 1972). Sato et al. (1986) reported that CPPs injected into the lumen of a ligated loop of small intestine enhanced absorption of calcium from the loop. On the other hand, Brommage et al. (1991) did not find any stimulating effect of CPPs in intestinal calcium absorption in rats eating a normal meal. Thus, the physiological role of CPPs may be due to inhibition of precipitation of calcium phosphate. A study by Yuan and Kitts (1991) in an animal system model could not demonstrate any improvement in calcium catabolism from diets containing CPP. CPPs-Ca complexes may enhance calcium absorption in the small intestine. However, further research is needed to confirm this.

Some peptides show antihypertensive activity. These peptides are called casokinins, which are inhibitors of the ACE. Angiotensin II decreases the renal output and increases water retention. ACE plays an important role in blood pressure regulation. This enzyme catalyses production of angiotensin II (which is a vasoconstrictor) and inactivation of bradykinin (which is a vasodilator). These peptides exhibit ACE inhibitory activity. Some specific inhibitors of ACE have been proven to be useful as antihypertensive drugs (Meisel \& Schlimme 1994).

The antihypertensive effect of orally administered doses of Calpis sour milk or peptides (Val-Pro-Pro or Ile-Pro-Pro) on spontaneous hypertensive rats was studied by Nakamura et al. (1995). The sour milk or peptides decreased systolic blood pressure $6-8 \mathrm{~h}$ postadministration. Antihypertensive effect of sour milk containing two peptides Val-Pro-Pro and Ile-Pro-Pro was tested in hypertensive patients. Systolic blood pressure was decreased significantly at 4 and 8 weeks after the beginning of ingestion, suggesting a mild pharmacological effect of antihypertensive peptides. Sekiya et al. (1992) also studied the application of casein hydrolysate against hypertension in human volunteers.

Some peptides have shown antithrombotic activities. There are a number of similarities between clotting of blood and that of milk. Rennin or chymosin hydrolyses the peptide bond between residues 105 and 106 (Phe-Met) of $\kappa$-casein. There are structural and functional homologies between the dodecapeptide of fibrinogen and the 106-110 sequence of $\kappa$-casein (called casopiastrin). Casopiastrin has been shown to have antithrombotic activity as this peptide inhibits binding of fibrinogen on platelets (Fiat et al. 1993).

Most of the claimed physiological properties of the 
Table 5. Bioactive peptides derived from whey proteins

\begin{tabular}{lclll}
\hline Precursor protein & Fragment & \multicolumn{1}{c}{ Peptide sequence } & Name & \multicolumn{1}{c}{ Function } \\
\hline$\alpha$-Lactalbumin & $50-53$ & Tyr-Gly-Leu-Phe & $\alpha$-Lactorphin & Opioid agonist ACE inhibition \\
$\alpha$-Lactoglobulin & $102-105$ & Tyr-Leu-Leu-Phe & $\beta$-Lactorphin & Non-opioid stimulatory effect on ileum \\
& $142-148$ & Ala-Leu-Pro-Met His-Ile-Arg & - & ACE inhibition \\
& $146-149$ & His-Ile-Arg-Leu & $\beta$-Lactotensin & lleum contraction \\
Bovine serum albumin & $399-404$ & Tyr-Gly-Phe-Gln-Asp-Ala & Serorphin & Opioid \\
& $208-216$ & Ala-Leu-Lys-Ala-Trp-Ser-Val-Ala-Arg & Albutensin A & lleum contraction ACE inhibition \\
Lactoferrin & $17-42$ & Lys-Cys-Arg-Arg-Trp-Glu-Trp-Arg-Met-Lys- & Lactoferricin & Antimicrobial \\
& & Lys-Leu-Gly-Ala-Pro-Ser-lle-Pro-Ser-Ile- & & \\
& Thr-Cys-Val-Arg-Arg-Ala-Phe & & \\
& & &
\end{tabular}

Adapted from: Korhonen et al. (1998).

casein-based bioactive peptides have been carried out in vitro or in animal model systems and these hypothesised properties remain to be proven in humans.

\section{Physiological role of whey protein-based bioactive substances}

Whey proteins comprise approximately $20 \%$ of total milk proteins (Table 1). The whey proteins are not coagulated by acid and are resistant to the action of chymosin. As a result these proteins remain present in acid and rennet wheys. $\alpha$ Lactalbumin is one of the main proteins in human milk. $\alpha$-Lactalbumin contains readily digestible amino acids. $\beta$ Lactoglobulin represents about half the total protein in whey of cows' milk. However, it is absent from human milk (Table 1).

Many whey proteins are claimed to possess physiological properties. Bovine whey contains metal binding proteins, imunoglobulins, growth factors and hormones. Bioactive peptides obtained from whey proteins and their physiological effects have been less extensively studied than those from caseins. Most of the functions of whey proteins are related to the immune or digestive systems. Wong and Watson (1995) have shown immunostimulatory functions of whey proteins. McIntosh et al. (1995) have reported anticarcinogenic effects of whey proteins in mice and rats. However, further research is warranted to substantiate these findings. Antimicrobial properties of these whey protein fractions are well established. Lactoperoxidase, lactoferrin, and imunoglobulins have already been commercialised.

Some of the bioactive peptides obtained from whey proteins include $\alpha$-lactorphin, $\beta$-lactorphin, albutensin A and $\beta$-lactotensin. Serorphins obtained from bovine blood serum albumin have shown opioid activity (Table 5) (Tani et al. 1994).

Minor whey proteins such as lactoferrin, lactoperoxidase, lysozyme and immunoglobulins are considered antimicrobial proteins. Lactoferrin is a dominant whey protein in human milk and plays an important role in iron uptake in the intestine (Hutchens et al. 1994; Viljoen, 1995). Bovine lactoferrin is homologous to human lactoferrin. The concentration of lactoferrin in bovine colostrum and milk is about $1.5-5 \mathrm{mg} / \mathrm{ml}$ and $0 \cdot 1 \mathrm{mg} / \mathrm{ml}$, respectively (Tsuji et al. 1990). In human milk and colostrum the reported levels are $2-4 \mathrm{~g} / \mathrm{l}$ and $6-8 \mathrm{~g} / \mathrm{l}$, respectively. This indicates that lactoferrin is even more important for humans than for bovine species. The presence of high concentrations of lactoferrin in colostrum and the passing on to the newborn suggests the involvement of lactoferrin in the primary defence system against pathogenic bacteria (Kussendrager, 1993). Lactoferricin is a single peptide consisting of 25 amino acid residues. A similar active peptide consisting of 47 amino acid residues has been obtained from human lactoferrin. The molecule is folded into two globular units, each capable of binding one ferric $\left(\mathrm{Fe}^{3+}\right)$ ion.

Some whey proteins are known to contain bioactive peptides with weak opioid activity including serorphin and albutensin from the serum albumen fraction, lactoferroxin from lactoferrin and lactotensin from $\beta$-lactoglobulin.

Lysozyme is an antimicrobial enzyme found in colostrum and human milk. The enzyme hydrolyses $\beta-1 \rightarrow 4$ linkages between $N$-acetylmuramic acid and 2-acetylamino-2-deoxy-D-glucose residues in bacterial cell walls, resulting in cell lysis. The concentration of lysozyme in colostrum and normal milk is about $0.14-0.7$ and $0.07-$ $0.6 \mathrm{mg} / \mathrm{l}$, respectively (Korhonen, 1977). Lysozyme is a $15 \mathrm{kDa}$ single-chain protein. The amino acid content of bovine milk lysozyme is different from that of human milk and egg white lysozyme.

Lactoperoxidase is a major antibacterial agent in colostrum. The enzyme, in the presence of $\mathrm{H}_{2} \mathrm{O}_{2}$ catalyses the oxidation of thiocyanate $\left(\mathrm{SCN}^{-}\right)$and produces an intermediate product with antimicrobial properties. The concentration of lactoperoxidase in colostrum and milk is about $11-45 \mathrm{mg} / \mathrm{ml}$ and $13-30 \mathrm{mg} / \mathrm{ml}$, respectively (Korhonnen, 1977).

Immunoglobulins are not transferred across the placenta to the mammalian fetus and hence babies and calves are born with very low concentrations of serum immunoglobulins. Immunoglobulins occur in high concentration in bovine or human colostrum and the absorption of immunoglobulins occurs from colostrum to provide passive immunity after birth. The antibodies protect the newborn against infections. The major immunoglobulins in human milk are $\operatorname{IgA}$. IgG1 is the main immunoglobulin type in colostrum, whereas IgM, IgA and IgG2 are present at lower concentrations. Colostrum contains approximately 100 times higher concentrations of immunoglobulins than milk.

$\alpha$-Lactorphin produced from $\alpha$-lactoglobulin showed weak opioid activity, whereas the effects of $\beta$-lactorphin produced from $\beta$-lactoglobulin are less clear. In studies by McIntosh et al. (1993, 1995) and Regester et al. (1996) whey-protein fed rats showed the lowest incidence of colon cancer $(30 \%)$ compared to $55 \%$ for meat diet and $60 \%$ 
Table 6. Protective factors in human milk

\begin{tabular}{lll}
\hline Protective factor & Pathogen & Mechanism \\
\hline Oligosaccharides & Clostridia, Escherichia coli, various pathogens & Prebiotics/bifidobacteria inhibit growth of pathogens \\
Oligosaccharides & Rotavirus & Prebiotics/bifidobacteria improve immune response \\
Oligosaccharides & Campylobacter jejuni & Binds bacterium \\
Oligosaccharides & Streptococcus pneumoniae & Binds bacterium \\
Fucosylated oligosaccharides & Enterotoxin E.coli & Binds stable toxin \\
Mucin & E. coli & Binds bacterium \\
GM1 ganglioside & Vibrio cholera & Binds toxin \\
GM1 gangliosides & C. jejuni & Binds toxin \\
GM1 gangliosides & Enterotoxigenic E. coli & Binds labile toxin \\
Mannosylated glycoprotein & Enterohaemorrhagic E. coli & Binds toxin \\
Lactoferrin & Gram -ve and Gram +ve bacteria & Iron sequestration/membrane disruption
\end{tabular}

for soy diet. $\alpha$-Lactalbumin and $\beta$-lactoglobulin have physiological properties of whey proteins including immunoenhancing effects. The possible role of $\alpha$-lactalbumin as an antitumour agent is being investigated (Hakansson et al. 1995) (Table 6).

The two peptides, $\alpha$-lactorphin and $\beta$-lactorphin have been shown to cause contraction of smooth muscles similar to morphine. Albutensin and $\beta$-lactotensin cause contraction of guinea-pig ileum longitudinal muscle. Whey proteins including $\alpha$-and $\beta$-lactorphin and albutensin appear to have ACE inhibitory activity.

The specific roles of various immunoglobulins, lactoferrin and lactoperoxidase in protecting the newborn calf are well established. $\beta$-Lactoglobulin can bind retinol and can transport this into the small intestine (McLeod et al. 1996)

Lactoferrin exhibits both bacteriostatic and bacteriocidal activity against a range of microorganisms. Lactoferrin also causes release of lipopolysaccharide molecules from the outer membrane of the Gram-negative bacteria and acts directly as an antibiotic. Lactoferrin has been found to inhibit the growth of Escherichia coli, Salmonella typhimurium, Shigella dysenteriae, Listeria monocytogenes, Bacillus stearothermophilus and Bacillus subtilis (Batish et al. 1988; Payne et al. 1990; Saito et al. 1991). The antimicrobial effect is mainly on the organisms that require iron as lactoferrin chelates iron thereby depriving the organisms of a source of this nutrient. Lactoferrin interacts with the bacterial cell membrane leading to permeability changes and causes release of lipopolysaccharide from the outer membrane of the Gram-negative bacteria. A direct interaction between lysozyme and lactoferrin was observed with Micrococcus luteus (Yamauchi, 1992). Lactoferricin, a peptide derived from bovine lactoferrin due to action of pepsin has been found to have antimicrobial activity against various bacteria and Candida albicans (Jones et al. 1994).

Milk lysozyme is active against a number of Grampositive and some Gram-negative bacteria. There seems to be a synergistic action of lysozyme and lactoferrin against $E$. coli as the latter damages the outer membrane of Gramnegative bacteria and the organism becomes susceptible to lysozyme. Combinations of lysozyme and lactoferrin are more bacteriostatic than either of the proteins alone (Suzuki et al. 1989). The enzyme is toxic to Gram-positive and Gram-negative bacteria such as Pseudomonas aeruginosa, Salmonella typhimurium, and Listeria monocytogenes.
Gram-negative organisms may be inhibited or killed. Gram-positive bacteria are more resistant and are generally only inhibited in their growth.

Several clinical studies (reviewed by Goldman, 1989; Davidson, 1996, Pakkanen \& Aalto, 1997 have demonstrated efficacy of immune milk preparations in the therapy of gastrointestinal diseases. Immune milk preparations are protective against rotavirus infections in children, enteropathogenic or enterotoxigenic $E$. coli infections, and Helicobacter pylori.

\section{Milk sugars and other milk-based bioactive components and their physiological effects}

Human milk contains a number of protective factors including oligosaccharides, mucin and gangliosides. These oligosaccharides are complex sugar structures attached to lactose. The concentration of oligosaccharides in human milk can range from 10 to $20 \mathrm{~g} / \mathrm{l}$. Human milk contains more types and higher amounts of oligosaccharides than cow milk. Oligosaccharide structures can also comprise the carbohydrate portion of glycoconjugates, such as glycolipids and glycoproteins. Glycoproteins have oligosaccharides attached to a protein. Lactoferrin is one of the major glycoproteins in human milk whey. Glycoprotein in human milk inhibits the binding of enterohaemorrhagic E. coli (Newburg \& Newbauer, 1995).

Lactose has been reported to enhance calcium absorption. Lactose can be used to produce lactulose and lactooligosaccharides. Lactulose is used as a promoter of probiotic bacteria and its use is now widespread in infant formulas. Lacto-oligosaccharides are also used as probiotic growth promoters. Lacto-oligosaccharides are produced from lactose by enzymatic processes involving the reverse of the lactose hydrolysis reaction by $\beta$-D-galactosidase enzyme. The oligosaccharides in human milk inhibit the binding of host cells by enteropathogenic $E$. coli, Campylobacter jejuni and Streptococcus pneumoniae to the target cells. Fucosylated oligosaccharide fraction in human milk protects against enterotoxigenic $E$. coli.

Mucin is a long macromolecule in human milk and links with oligosaccharides. Human milk mucin complex binds to rotavirus and inhibition of rotavirus has been reported. Mucin-associated glycoprotein (lactadherin) is responsible for binding with rotavirus (Yolken et al. 1992).

Although the protein fraction of milk has been widely 
studied in terms of bioactive compounds, there are other compounds that have shown physiological significance. Calcium is thought to play a role in the regulation of blood pressure. There is some epidemiological evidence that higher intakes of calcium, especially from dairy products are associated with maintenance of blood pressure. However, more research is needed to substantiate this. The possible protective role of calcium in prevention of colon cancer has been investigated by researchers at the Dutch Dairy Research Institute (NIZO) in Ede. It has been hypothesised that the main factor involved in promotion of colon cancer is the presence of bile salts. Milk appears to play some role in providing calcium phosphate which binds bile salts in order to prevent their toxic effect (van der Meer \& Lapre, 1991).

Lipid-based bioactive compounds in milk include fatty acids. The role of conjugated linoleic acid for inhibition of cancer and atherosclerosis has been studied (Pariza, 1997; Schmelz \& Merrill, 1997). Traditional dairy products such as yogurt, kefir and koumiss have been consumed for centuries throughout the world. A number of health benefits have been claimed to be associated with the consumption of fermented milk products. The recent trend is to incorporate probiotic organisms such as Lactobacillus acidophilus and bifidobacteria known as AB cultures in fermented dairy foods (Dave \& Shah, 1997). The generally accepted definition of 'probiotics' is that they are live microbial food or feed supplements that provide a beneficial effect on hosts (human or animal) by improving the microbial balance in the intestine. Probiotic products are viewed as healthy foods by consumers. The intake of these bacteria is reported to help restore the balance in the intestinal microflora, which may have been lost due to stress, antibiotic use or due to illness.

L. acidophilus is found naturally in the upper gastrointestinal tract and bifidobacteria occur in the large intestine. The beneficial effects of the presence of bifidobacteria in the gastrointestinal tract are dependent on their viability and metabolic activity. The growth of bifidobacteria is dependent on the presence of complex carbohydrates known as bifidogenic factors such as oligosaccharides. Some of these bifidogenic factors can be obtained from lactose including lactulose, lactitol or lactosucrose. These complex oligosaccharides are not digested by enzymes or acid of the stomach and pass on to the colon undigested. Here they are fermented by bifidobacteria and stimulate the growth of bifidobacteria. These complex oligosaccharides which promote the growth of beneficial organisms are referred to as prebiotics. 'Prebiotic' is a term to describe factors such as those found in the human milk that promote the growth of desirable bacteria in the intestine (Gibson \& Roberfroid, 1995). This term also includes what is referred to as 'bifidus factors'. The effects of three oligosaccharides $(\beta$ fructo-oligosaccharides (FOS), $\beta$-galacto-oligosaccharides (BOS) and $\alpha$-gluco-oligosaccharides (GOS)) on metabolism of intestinal microflora in germ-free rats inoculated with human faecal flora have been studied (Djouzi \& Andrieux, 1997). FOS and BOS were preferred by bifidobacteria the number of which increased by $2 \log$ cycles as compared with the rats on control diets. Analysis of caecal content revealed a decrease in $\mathrm{pH}$. The products that contain both prebiotics and probiotics are referred to as 'synbiotics'. Japan is the world leader in probiotic and prebiotic products.

Breast-fed infants have a much higher percentage of Bifidobacterium bifidum than formula-fed infants. The latter group contained more adult microflora including coliform bacteria. Bifidobacteria produce acetic acid, butyric acid, lactic acid and pyruvic acid. The lactic acid and acetic acid account for $>90 \%$ of organic acids produced (Lankaputhra, 1997; Lankaputhra \& Shah, 1998). It is widely accepted that because of acid production by $L$. acidophilus and bifidobacteria, the enteropathogenic bacteria are unable to grow. The growth of clostridia and $E$. coli, when cocultured with bifidobacteria, has been found to be inhibited even at neutral $\mathrm{pH}$ suggesting that acid production may not be solely responsible for inhibition. Metabolites produced by bifidobacteria may be partly responsible.

Certain nitrogen containing oligosaccharides stimulate growth of bifidobacteria. Human milk glycopeptides and glycoproteins are also thought to be stimulating the growth of bifidobacteria. These factors are absent from cow milk. The bifidus factor associated with casein may be attributable to the oligosaccharide moiety of those molecules.

Bovine lactoferrin has been demonstrated to stimulate the in vitro growth of human Bifidobacterium species (Petschow \& Talbott, 1991). However, there is a lack of in vivo data demonstrating that addition of lactoferrin to infant formulas decreases the presence of harmful bacteria (Roberts et al. 1992).

Lactoferricin is highly effective against a broad range of Gram-positive and Gram-negative bacteria including Listeria, E. coli, Salmonella and Campylobacter, but not against several strains of Bifidobacterium. Lactoferricin is also effective against Candida albicans, which is the most important fungal pathogen of humans.

Protective effects of fucosylated oligosaccharides and glycoproteins and glycolipids against enterotoxigenic $E$. coli have been reported (Newburg et al. 1990). This inhibition appears to be associated with acidic glycolipids that contain sialic acid gangliosides. Oligosaccharides in human milk interfere with the attachment of Haemophilus influenzae and Streptococcus pneumoniae (Goldman \& Goldblum, 1995).

\section{Conclusions}

Dairy products can be considered as physiological foods and precursors for several bioactive substances. However, further research is needed particularly in humans to fully substantiate the role of the bioactive substances. Once the information regarding health benefits is accepted by the public, incorporation of whey proteins and milk sugar in the promotion of health benefits becomes a strong marketing tool. A major avenue for increasing the beneficial physiological effects of dairy products is likely to be probiotic foods. Over the past decade, Australia, North America, Europe, and Japan have seen a tremendous increase in the consumption of probiotic products. Probiotic foods are becoming increasingly popular. The combination 
of whey proteins as physiological foods and a precursor of bioactive substances and milk sugar as prebiotics along with probiotic bacteria to modify the gastrointestinal flora have the potential to provide a complete food for maximum health benefits.

\section{References}

Antila P, Paakkari I, Jarvinen A, Mattila MJ, Laukkanen M, Pihlanto-Leppala A, Mantsala P \& Hellman J (1991) Opioid peptides derived from in vitro proteolysis of bovine whey proteins. International Dairy Journal 1, 215-229.

Batish VK, Chander H, Zumdegeni KC, Bhatia KL \& Singh RS (1988) Antibacterial activity of lactoferrin against some common food-borne pathogenic organisms. Australian Journal of Dairy Technology 5, 16-18.

Bicknell RS (1985) Endogenous opioid peptides and hypothalamic neuroendocrine neurons. Scandanavian Endocrinology 107, 43.

Brommage R, Juillerat MA \& Jost R (1991) Influence of casein phosphopeptide and lactulose on intestinal calcium absorption in adult female rats. Lait 71, 173-180.

Daniel H, Vohwinkel M \& Rehner G (1990) Effect of casein and $\beta$-casomorphin on gastrointestinal motility in rats. Journal of Nutrition 120, 252-257.

Dave RI \& Shah NP (1997) Viability of yoghurt and probiotic bacteria in yoghurt made from commercial starter cultures. Interernational Dairy Journal 7, 31-41.

Davidson GP (1996) Passive protection against diarrheal disease. Journal of Paediatric Gastroenterology and Nutrition 23, 207 212.

Djouzi Z \& Andrieux C (1997) Compared effects of three oligosaccharides on metabolism of intestinal microflora in rats inoculated with human faecal flora. British Journal of Nutrition 78, 313-324

Fiat AM, Migliore-Samour D, Jolles P, Drouet I, Bal Dit Soitier C \& Caen J (1993) Biologically active peptides from milk proteins with emphasis on two examples concerning antithrombotic and immunomodulating activities. Journal of Dairy Science 76, 301-310.

Gibson GR \& Roberfroid MB (1995) Dietary modulation of the human colonic microbiota: introducing the concept of prebiotics. Journal of Nutrition 125, 1401-1412.

Goldman AS (1989) Immunologic supplementation of cow's milk formulations. Bulletin of the International Dairy Federation 244, 38-42.

Goldman AS \& Goldblum RM (1995) Defense agents in milk: A. defense agents in human milk. In Handbook of Milk Composition, pp. 727-748 [R Jensen, editor]. New York: Academic Press.

Hutchens TW, Rumball SV \& Lonnerdal B (1994) Lactoferrin: structure and function. Advances in Experimental Medical and Biological 357, 1-298.

Jelen P \& Lutz S (1998) Functional milk and dairy products. In Functional Foods: Biochemical and Processing Aspects, pp. 357-380 [FG Mazza, editor]. Lancaster: Technomic Publ. Co., Inc.

Jones EM, Smart A, Bloomberg G, Burgess L \& Millar MR (1994) Lactoferricin, a new antimicrobial peptide. Journal of Applied Bacteriology 77, 208-214.

Kitts DD \& Yuan YV (1992) Caseinophosphopeptides and calcium bioavailability. Trends in Food Science and Technology 3, 31 .

Korhonen H (1977) Antimicrobial factors in bovine colostrum. Journal of the Scientific Agricultural Society of Finland 49 , 434-447.
Korhonen H, Pihlanto-Leppala A, Rantamaki P \& Tupasela T (1998) The functional and biological properties of whey proteins: prospects for the development of functional foods. Agriculture and Food Science in Finland 7, 283-296.

Kussendrager K (1993) Lactoferrin and lactoperoxidase: bioactive milk proteins. International Food Ingredients 6, 17-21.

Lahov E \& Regelson W (1996) Antibacterial and immunostimulating casein-derived substances from milk: caseicidin, isracidin peptides. Food and Chemical Toxicology 34, 131-145.

Lankaputhra WEV (1997) Viability and therapeutic properties of probiotic bacteria. PhD Thesis, Victoria University of Technology, Melbourne, Victoria, Australia.

Lankaputhra WEV \& Shah NP (1998) Antimutagenic properties of probiotic bacteria and of organic acids. Mutation Research 397, 169-182.

Loukas L, Varoucha D, Ziodrou C, Straty RA \& Kice WA (1983) Opioid activities and structure of $\alpha$-casein-derived exorphins. Biochemie 22, 4567.

McIntosh GH, Jorgensen L \& Royle PJ (1993) The potential of an insoluble dietary fibre-rich source from barley to protect from DMH-induced intestinal tumors in rats. Nutrition and Cancer 19, 213.

McIntosh GH, Regester GO, Le Leu RK, Royle PJ \& Smithers GW (1995) Dairy proteins protect against dimethylhydrazineinduced intestinal cancers in rats. Journal of Nutrition $\mathbf{1 2 5}$, 809-816.

McLeod A, Fedio W, Chu L \& Ozimek L (1996) Binding of retionoic acid to $\beta$-lactoglobulin variants $A$ and $B$ : effect of hepatic and tryptic digestion on the protein-ligand complex. Milchwissenschaft 51, 3-7.

Maruyama S \& Suzuki H (1982) A peptide inhibitor of angiotensin I-converting enzyme inhibitor in the tryptic hydrolysates of casein. Agriculture Biological Chemistry 46, 1393.

Maruyama S, Nakagomi K, Tomizuka N \& Suzuki H (1985) Angiotensin-converting enzyme inhibitor derived and enzymatic hydrolysate of casein II. Isolation and bradykininpotentiating activity on uterus and ileum the ileum of rat. Agriculture and Biological Chemistry 51, 1581.

Maubois JL \& Leonil J (1989) Peptides du lait a activite biologique. Lait 69, 245.

Meisel H \& Schlimme E (1990) Milk proteins: precursors of bioactive peptides. Trends in Food Science and Technology 1, 42-43.

Meisel H \& Schlimme E (1994) Inhibitors of angiotensin Iconverting enzyme derived from bovine casein (casokinins). In $\beta$-Casomorphins and Related Peptides: Recent Development [V Branil and $\mathrm{H}$ Teschemacher, editors]. Weinheim: VCH, Germany.

Migliore-Samour D, Floch F \& Jolles P (1989) Biologically active casein peptides implicated in immunomodulation. Journal of Dairy Research 56, 357.

Mullally MM, Meisel H \& FitzGerald RJ (1996) Synthetic peptides corresponding to $\alpha$-lactalbumin and $\beta$-lactoglobulin sequences with angiotensin-I-converting enzyme inhibitory activity. Biological Chemistry Hoppe-Seyler 377, 259-260.

Naito H, Kawakami A \& Imamura T (1972) In vivo formation of phosphopeptide with calcium-binding property in the small intestinal tract of the rat fed on casein. Agriculture and Biological Chemistry 36, 409-415.

Nakamura Y, Yamamoto N, Kumi S \& Takano T (1995) Antihypertensive effect of sour milk and peptides isolated from it that are inhibitors to angiotensin-I converting enzyme. Journal of Dairy Science 78, 1253-1257.

Newburg DS \& Newbauer SH (1995) Carbohydrates in milk. In Handbook of Milk Composition, pp. 273-349 [RG Jensen, editor]. San Diego: Academic Press. 
Newburg DS, Pickering LK, McCluer RH \& Cleary TG (1990) Fucosylated oligosaccharides of human milk protect sucling mice from heat stable enterotoxin of Escherichia coli. Journal of Infectious Diseases 162, 1075-1080.

Newburg DS \& Street JM (1997) Bioactive materials in human milk. Nutrition Today 32, 191-201.

Pakkanen R \& Aalto J (1997) Growth factors and antimicrobial factors of bovine colostrum. International Dairy Journal 7, 285-297.

Pariza MW (1997) Conjugated linoleic acid: a newly recognized nutrient. IFT Annual Meeting Orlando, FL, Abstract 15-3.

Parker F, Migliore-Samour D, Floch F, Zerial A, Werner GH, Jolles J, Casaretto M, Zahn H \& Jolles P (1984) Immunostimulating hexapeptide from human casein: amino acid sequence, synthesis, and biological properties. European Journal of Biochemistry 145, 677.

Paroli E (1988) Opioid peptides from food (the exorphins). World Review of Nutrition and Dietetics 55, 58-97.

Payne KD, Davidson PM \& Oliver SP (1990) Influence of bovine lactoferrin on the growth of Listeria monocytogenes. Journal of Food Protection 53, 468-472.

Petschow BW \& Talbott BW (1991) Response of Bifidobacterium species to growth promoters in human and cow. Pediatric Research 29, 208-213.

Regester GO, McIntosh GH, Lee VWK \& Smithers GW (1996) Whey proteins as nutritional and functional food ingredients. Food Australia 48, 123-126.

Reynolds EC (1994) Anticariogenic casein-phosphopeptide. 24th International Dairy Congress, Melbourne, Australia, 18-22 September.

Roberts AK, Chierici R, Sawatzki G, Hill MJ, Volpato S \& Vigi V (1992) Supplementation of an adapted formula with bovine lactoferrin. I. Effect on the infant fecal flora. Acta Paediatrica 81, 119-124.

Saito H, Miyakawa H, Tamura Y, Shimamura S \& Tomita M (1991) Potent bacteriocidal activity of bovine lactoferrin hydrolysate repoduced by heat treatment at acidic $\mathrm{pH}$. Journal of Dairy Science 74, 3724-3730.

Sato R, Noguchi T \& Naito H (1986) Casein phosphopeptide enhances calcium absorption from the ligated segment of rat small intestine. Journal of Nutritional Sciences and Vitaminology 32, 67-76.

Schlimme E \& Meisel H (1993) Bioactive peptides: structural physiological and analytical aspects. Newsletter of the IDF 139, (Suppl.), 57-71.

Schmelz EM \& Merrill AH (1997) Milk sphingolipids: A new category of functional food. IFT Annual Meeting, Orlando, FL, Abstr 15-4

Sekiya S, Kobayashi Y, Kita E, Imamura Y \& Toyama S (1992) Antihypertensive effects of tryptic hydrolysates of casein on normotensive and hypertensive volunteers. Journal of Japanese Society of Nutrition and Food Science 45, 513.

Suzuki T, Yamauchi K, Kawase K, Tomita M, Kiyasawa I \& Okongi S (1989) Collaborative bacteriostatic activity of bovine lactoferrin with lysozyme against $E$. coli 0111 . Agriculture and Biological Chemistry 53, 1705-1706.

Svedberg J, De Haas J, Leimenstoll G, Paul F \& Teschemacher H (1985) Demonstration of $\beta$-casomorphin immunoreactive materials in in vivo digests of bovine milk and in small intestine contents after bovine milk ingestion in adult humans. Peptides 6, 625.

Tani F, Shiota A, Chiba H \& Yoshikawa M (1994) Saerorphin, an opioid peptide derived from bovine serum albumine. In $\beta$ Casomorphins and Related Peptides: Recent Developments [V Brandtl and $\mathrm{H}$ Teschemacher, editors]. Weinheim: VCH, Germany.

Teschemacher H (1987) Casein derived opioid peptides: physiological significance? Advances in Bioscience 65, 41.

Tirelli A, De Noni I \& Resmini P (1997) Bioactive peptides in milk products. Italian Journal of Food Science 9, 91-98.

Tsuji S, Hirata Y, Mukai F \& Ohtagaki S (1990) Comparison of lactoferrin content in colostrum between different cattle breeds. Journal of Dairy Science 73, 125-128.

Van der Meer R \& Lapre JA (1991) Calcium and colon cancer. Bulletin of the International Dairy Federation 255, 55-59.

Viljoen M (1995) Lactoferrin: a general review. Haematologica 80, 252-267.

Walstra P \& Jenness R (1984) Dairy Chemistry and Physics. New York: John Wiley.

Wong CW \& Watson DL (1995) Immunomodulatory effects of dietary whey proteins in mice. Journal of Dairy Research 62 , 359-368.

Yamamoto N (1997) Antihypertensive peptides derived from food proteins. Biopolymers 43, 129-134.

Yamauchi K (1992) Biologically functional proteins of milk and peptides derived from milk proteins. Bulletin of the International Dairy Federation 272, 51.

Yen SSC, Quingley ME, Reid RL, Ropert JF \& Cetei NS (1985) Neuroendocrinology of opioid peptides and their role in the control of gonadotrophin and prolactin secretion. American Journal of Obstetrics and Gynaecololgy 152, 485.

Yolken RH, Peterson JA, Vonderfech SL, Fouts ET, Midthun K \& Newburg DS (1992) Human milk mucin inhibits rotavirus replication and prevents experimental gastroenteritis. Journal of Clinical Investigation 90, 1984-1991.

Yuan YV \& Kitts DD (1991) Confirmation of calcium absorption and femoral utilisation in spontaneously hypertensive rats fed casein phosphopeptide diets. Nutrition Research 11, 12571272. 